DOI: 10.2478/ausp-2021-0002

\title{
Natural Disasters and the Rise of the Modern Prometheus
}

\author{
Petru Ştefan IONESCU \\ “1 Decembrie 1918” University of Alba Iulia (Alba Iulia, Romania) \\ Department of Philology \\ petru.ionescu@uab.ro
}

\begin{abstract}
The aim of this paper is to present a specific literary evolution in the context of catastrophes brought by war, revolutions, pandemics, and natural disaster. Discussing works by Daniel Defoe and the Byron-Shelley circle, we will observe how traumatic events influenced literary and artistic expression, reflecting the social, political, and historical context of the authors' lives. People tend to relate to heroes and myths more easily in times of crisis, hoping to find force and motivation in their fight for survival and improvement. The myth of Prometheus as a benefactor of mankind was one of the most influential for romantics, with Byron and Shelley casting him as a revolutionary hero that helps man combat the tyranny of his oppressors. Mythopoeic romantic poets such as Blake, Byron, and Shelley hoped to animate their fellows with their revolutionary creation into fighting against autocracy and for their liberties. Mary Shelley, on the other hand, turned Prometheus from the mythical ancient hero of humanity into the modern romantic anti-hero, creating in the process the first modern work of science-fiction.
\end{abstract}

Keywords: Prometheus, myth, modern, pandemic, disasters

\section{Introduction}

Today, with the global fear caused by the pandemic, people need to relate to previous similar experiences, be they real, historical events like the Spanish Flu or fictional ones. There has been an abundance of news relating to the previous major pandemic one hundred years ago, and there are reports in the news about readers showing a sudden interest in representative works of fiction depicting pandemics such as Gabriel García Márquez's Love in the Time of Cholera and Albert Camus's The Plague.

Considering literature as an expression of human thoughts and observations on their environment since the earliest times, catastrophic events of major impact 
on human lives and societies have been reflected in literature since its beginning. Some of the oldest recorded texts hold references to cataclysmic events that changed the course of history and the fate of mankind. The Sumerian Epic of Gilgamesh, the Greek mythology, the Bible, etc. present people's views about the origin and creation of the world and humanity. The unexplainable was attributed to supernatural dimensions. Gods and titans, angels and demons populated the first sacred texts, where people were merely imperfect and impotent reflections of their creators. Amongst them, the mythical figure of Prometheus stands out, as a god of fire that helped people more than any other, and even sacrificed himself for the benefit of humankind. The myth of Prometheus, a myth of creation, is relevant for our discussion because it is about the creation of life and about the consequences of that creation, as well as about the fate of that creation. In the revolutionary torments that were shaking Europe at the beginning of the nineteenth century, a new fate for humanity was at stake. Rebellion against an oppressive earthly authority that had been long established on foundations of divine empowerment took forms that included revolt against all manifestations of oppression and authority, religious included. It is this idealized and revolutionary interpretation of the myth that appealed to English romantic poets like Blake, Byron, or Percy Shelley, and, somewhat differently, to Mary Shelley. Percy Bysshe Shelley and his friend Lord Byron had a vision of Prometheus that embodied the Titan as a liberator of humanity, while Mary Shelley's approach was rather one of a failure, a Romantic anti-hero that was trying to help the human race, but whose endeavours, due to his own weak nature, ended inevitably in chaos and disaster.

\section{Between Myth and Reality: Natural Disasters and Pandemics}

Man seems to have created the myths of his own origin and evolved together with those myths, in a reciprocal dependency. In the attempt to explain their place in the universe and their own creation and fate, people conceived myths to account for them. In the opinion of Northrop Frye, mythmaking has several important functions, control being the most necessary:

Man is a myth-making as well as a tool-using animal, but constant vigilance is needed to make sure that he keeps control of what he makes. For it is with myths as it is with technology: just as man invents the wheel and then talks about a wheel of fate or fortune overriding everything he does, so he creates gods and then announces that the gods have created him. He makes his own creation, in short, a power to stop himself from creating. $(2005,151)$ 
It is exactly that control of creation and the failure to exercise it that play a decisive role in the novel of Frankenstein and makes the modern Prometheus an anti-hero of humanity.

Myths and legends of the oldest times retain relations of catastrophic natural events that plague mankind. From the story of the flood, present in the Epic of Gilgamesh, the Greek mythology, and the Bible, to the ten plagues mentioned in the Exodus, disasters seem to have accompanied the difficult history of man as constant and terrible threats to his very existence and a present reminder of his fragility and constant exposure to the whims of higher powers. Scientists today believe they have found rational explanations for such ancient calamities: natural phenomena of extraordinary amplitude. Some of them attribute the ancient stories of the flood to events like the end of the last Ice Age, with the massive retraction of ice leaving behind immense quantities of water to be captured by the Black Sea and suddenly released into the Mediterranean, or a devastating eruption of the volcano on Santorini, causing a huge tsunami that swept away the entire coast of the Mediterranean Sea, obliterating ancient civilizations that were mostly developing on the coast. Science and religion may continue their modern debates as to the origins of such blurred ancient epic cataclysms, but historical records closer to our times can offer more precise information as to the natural changes, disasters, wars, revolutions, and pandemics that have afflicted humanity in modern times. Scientists have found that the northern hemisphere underwent a process of cooling from around 1300 to 1850, leading to dramatic events in European history. Towards the end of that period, the most powerful volcanic eruption ever recorded - the Tambora eruption of 1815 - contributed even further to dramatic climate change that was to influence the creation of some of the most daring literary expressions of modern times: Byron's and Percy Shelley's poems "Prometheus" and "Prometheus Unbound", John Polidori's The Vampyre, and Mary Shelley’s Frankenstein; or, The Modern Prometheus.

Pandemics have also been a constant reminder of human frailty when exposed to the uncontrollable forces of nature. This has most likely been so since the beginning of our history and, as present events remind us, is still the case. The great plagues that swept across Europe were documented as tragic witnesses and apocalyptical warnings for generations to come. The Black Death, the most devastating and fatal pandemic that is recorded to have ever hit humankind, is estimated to have killed $30-60 \%$ of Europe's population in the middle of the fourteenth century. It was the second great catastrophe of the century, after the Great Famine of 1315-1317 caused by crop failure related to the natural process of climate change that started the Little Ice Age. Survivors left their impressions in writing and in frescoes and paintings on church walls, leading to an artistic allegorical motif of the Middle Ages known as the Danse Macabre. Promoted by the works of German painter Hans Holbein the Younger in the sixteenth century, 
the theme was of much interest to nineteenth-century composers Franz Liszt and Camille Saint-Saëns.

After the late Middle Ages, the next major outbreak of pestilence to devastate England was the Great Plague of London (1665-1666), which killed nearly a quarter of London's population, approximately 100,000 people. It was followed the same year by the Great Fire of London, which left 7 out of 8 inhabitants of the City homeless. One of the best sources that documents the Great Plague of London with references to the Great Fire as well is Daniel Defoe's A Journal of the Plague Year, published in 1722. The book was written in a form that triggered from the beginning discussions related to its genre - documentary or fiction. It recollects the memories of a survivor of the Plague and Fire, a certain H. F., who has been associated with Defoe's uncle, Henry Foe, an eyewitness and survivor of the pestilence. The book, published under the initials H. F., gives a detailed account of the events in London during the plague, some of which bear striking resemblances with those of the COVID pandemic of our days. ${ }^{1}$

One specific social behaviour that can be noticed today, when people are already tired by the long pandemic and by the restrictive measures imposed on their lives, is that of relaxation before time, abandoning the lockdown and going back to business as usual, disregarding the sanitary measures meant for protection and prevention. It was not different 350 years ago: "yet as I have observed that the distemper intermitted often at first, so they were, as it were, alarmed and unalarmed again, and this several times, till it began to be familiar to them; and that even when it appeared violent, yet seeing it did not presently spread into the city, or the east and south parts, the people began to take courage, and to be, as I may say, a little hardened" (Defoe 1722, 15).

To add even further to the dramatics of the situation and to the increased apocalyptical fear and superstitious frenzy, cosmic events anticipated and accompanied the disasters, like a grim prediction of terrible punishments cast upon mankind. Two comets crossed the sky of London, one before the plague and another before the great fire. Although comets as natural phenomena were already understood by scientists and educated people, in the eyes of the many,

1 Orders of the Mayor of London in 1665:

"Feasting prohibited.

That all public feasting, and particularly by the companies of this city, and dinners at taverns, ale-houses, and other places of common entertainment, be forborne till further order and allowance; and that the money thereby spared be preserved and employed for the benefit and relief of the poor visited with the infection.

Tippling-houses.

That disorderly tippling in taverns, ale-houses, coffee-houses, and cellars be severely looked unto, as the common sin of this time and greatest occasion of dispersing the plague. And that no company or person be suffered to remain or come into any tavern, ale-house, or coffee-house to drink after nine of the clock in the evening, according to the ancient law and custom of this city, upon the penalties ordained in that behalf." (Defoe 1722, 35) 
they were warnings of divine sanctions to come. In times of crises, when all logical answers seem to fail, the return to mysticism and superstition appeals most conveniently to people, be it to try and explain the unexplainable, or to suggest the possible achievement of the seemingly impossible. The latter seems to have been put to work by English romantic poets and revolutionaries such as Blake, Byron, and Shelley and their ilk.

\section{A Premonition of Enlightened Thought: A Chain of Volcanic Eruptions to Change the World}

Mary Shelley chose to send the young Frankenstein to study in Germany, in the town of Ingolstadt. That choice cannot be by chance. Ingolstadt was known as the birthplace of the secret society of the Illuminati, founded by Bavarian professor Adam Weishaupt in that university town. The movement gained much influence and spread across Europe in the mid-1780s, before being banned by the Bavarian government. The Illuminati society is thought to have been a republican one that intended also to replace Christian religion with a new kind of religion based on reason. Such goals were more than welcome by the daughter of the revolutionary figures Mary Wollstonecraft and William Godwin, and the lover of radical republican and atheist anarchist Percy Shelley. Ingolstadt would become the perfect place for Frankenstein's initiation into the secrets of mysterious knowledge and out-of-the-ordinary experiments. One of the metaphoric images used by enlightened scholars and by the Illuminati was that of volcanic eruptions symbolizing the outburst of the repressed people through revolutions that would change the face of the world. Like in a volcanic eruption, immense tensions accumulated over centuries of social and political oppression would be released forcefully and unstoppably. The association of human uprising to the uncontrollable forces of nature unleashed was meant to illustrate that once liberated, man's freedoms would not be contained by any earthly or heavenly authority. Many saw the French Revolution as such an outburst. And some even believed that real volcanic eruptions contributed to and were associated with such human outbreaks.

In romantic literature nature was observed and invoked, even adulated more than ever. The end of the Little Ice Age, as the cooling from the fourteenth to the nineteenth centuries is known today, coincided with some other major natural outbreaks: volcanic eruptions that possibly led to social upheavals and revolutions, with consequent effects on literature and philosophy. The eruptions of the volcanoes Laki (Iceland, June 1783-February 1784), Vesuvius (Italy, 1794), and Tambora (Indonesia, April 1815) were three of the most powerful blasts recorded in history that are also associated with social and political events that 
led to dramatic consequences in human history. The Laki eruption of 1783-1784 is believed by some historians to have contributed to the sparks that ignited the French Revolution due to the climatic changes its clouds of volcanic ash caused in Europe, leading to famine and poverty in much of France. The eruption of Vesuvius in June 1794 coincided with the height of the Great Terror during the French Revolution and was interpreted by some as the announcement of its end the following month. The Tambora eruption of April 1815 is the largest volcanic eruption in recorded history, and its climatic consequences might have influenced the creation of some of the most original, remarkable, and enduring pieces of literature.

The global effect of the Tambora eruption was "the year without summer". 1816 is registered as a very cold, wet, and dark year in many parts of the northern hemisphere. In several parts of Central and Western Europe and New England the ashes of Tambora covered the skies and prevented the sun from casting enough light and warmth onto the earth, with calamitous effects on agriculture. Europe, already devastated by the long Napoleonic Wars, experienced in some of its regions a disastrous famine that caused people to leave their homes, wandering aimlessly throughout the country in extreme poverty and starvation. Switzerland and South Germany were hit especially hard. A terrible reminder of that famine is a coin issued by the city of Nuremberg in 1817, with the inscription: "O gieb mir Brod mich hungert" and "Verzaget nicht - Gott lebet noch" (Oh give me bread I am hungry - Do not be disheartened, God still lives)” (Brönnimann 2016, 32).

\section{Political Revolutions and Poetic Rebellion}

After some of the revolutionary ideals of the Enlightenment had been partially implemented at the beginning of the French Revolution, the Great Terror that followed and the end of the French Republic under Napoleon's military dictatorship and imperial ambitions was a devastating blow for many reformers, republicans, and liberals all over Europe. In Germany, Friedrich Schiller, also known as the "poet of freedom", was disappointed by the turn taken by the French Revolution, and dismissed the citizenship of honour that was granted to him by the French Republic. In England, William Godwin and his daughter Mary Wollstonecraft Godwin were also enthusiastic intellectuals with revolutionary views. Mary's mother, Mary Wollstonecraft, was one of the first public feminists, a liberal progressist, and author of the first feminist manifesto: A Vindication of the Rights of Woman (1792). William Godwin was an influential figure in British literature and society, considered to be one of the first influential representatives of British radicalism and anarchism. With such ancestry, Mary Wollstonecraft Godwin could not have fallen far from the tree. Within the influence of her 
parents' ideas lays also the explanation for her particular vision of the modern Prometheus, in contrast to the Byronic-Shelleyan ideal of the mythological hero, as we shall further explain.

Johann Wolfgang von Goethe's poem "Prometheus", published in 1789 - the year of the French Revolution -, is the first powerful and influential example of the modern image of Prometheus infused by the spirit of the Enlightenment. The enlightened man does not recognize Zeus's authority over humankind any longer and claims that he is capable and willing to decide over his own destiny. The enlightened spirit feels now liberated from the state of tutelage described in 1784 by Immanuel Kant in his essay on the meaning of Enlightenment. According to Kant's theory on Enlightenment, man was in a state of tutelage, not being able to manage his own destiny because he did not have the courage to use his own reason. Sapere aude - Dare to know is, according to Kant, the motto of the Enlightenment. Goethe's Prometheus, the embodiment of the spirit of the Enlightenment, makes it clear that he now has the knowledge and claims for himself the rule of the Earth:

Musst mir meine Erde Now you must leave alone Doch lassen stehn, My Earth for Me, Und meine Hütte, die du nicht gebaut, And my hut, which you did not build, Und meinen Herd, And my hearth, Um dessen Glut The glowing whereof

Du mich beneidest. You envy me. ${ }^{2}$

In a complete revolutionary turn, it is not man who envies the gods, but it is the supreme God that envies man.

\section{The Year without a Summer}

In the summer of 1816 - the year without a summer -, Mary Wollstonecraft Godwin was accompanying her lover, poet Percy Bysshe Shelley, in his selfimposed exile from England. Pressed by his creditors and tired of his trials for inheritance, Shelley flew from London and embarked for Europe on 3 May 1816, ten days after Lord Byron had done the same thing, also running away from his creditors, but additionally from a huge scandal caused by his relations with his half-sister Augusta and the divorce that it prompted. In the summer of 1816, Shelley and Byron met for the first time on the shores of Lake Geneva. The meeting had been arranged by Mary's half-sister Claire, who initiated an affair

2 Translation @ 9 Richard Stokes, author of The Book of Lieder, published by Faber, provided courtesy of Oxford Lieder (www.oxfordlieder.co.uk). 
with Lord Byron just before his going into the exile from which he would never return. Mary had started an affair with Percy Shelley two years earlier, when she was sixteen and the poet twenty-four. Percy was married and had a son with his wife Harriet. Mary's father, William Godwin, whom Percy came to visit as a mentor before engaging with Mary, banished him from the house and forbad Mary to see him. They fled to Europe taking Mary's half-sister Claire with them. During their journey through Europe, they took a tour on the Rhine, a strong attraction for the English in those days, with its castles, wild nature, and legends like the Nibelungenlied or the new fantasy of Loreley, created a few years earlier by Clemens Brentano. Many English people considered the Rhine and the nature and tales that enveloped it as the essence of romantic themes and motifs.

After such a romantic preamble, during which Mary Shelley came very close to the Frankenstein Castle near Darmstadt, and to the legends that surrounded it, our travellers would arrive two years later, in 1816, on the shores of Lake Geneva, determined to spend the summer there. But 1816 was not a common year. Switzerland, and Geneva in particular, was a place sought out by wealthy Europeans who, driven by romantic impulses, were rediscovering the wonders of nature's wild beauty. People went there to spend the cooler summers on the lake and take long trips to the spectacular mountains of Jura and Mont Blanc. The weather was generally very pleasant, allowing for long walks on the lake's shore and daily boat trips on the lake. But that particular year, after the Tambora eruption, was not a usual one. The pronounced cooling in temperature caused by the eruption one year earlier translated into cold, bad weather for most of the time. Meteorological surveys of that year in other parts of Switzerland indicate that only on three days in July did it not rain. There were 28 days of rain out of 31 , the rain typically falling for the entire day, as compared to 11 normally (Brönnimann $2016,20)$. There were unusual violent storms, like those of 13 June and the following days, confining the tourists and residents to the indoors for several days and nights. The spectacular storm was to inspire scenes in Mary Shelley's Frankenstein (1818) and The Last Man (1826) as well as in Byron's "Darkness" (1816). Shelley's group went for consecutive evenings in June to Villa Diodati, Byron's residence for the summer, and even spent some of the nights there due to the heavy rains. A common way to spend those evenings was to gather after dinner and discuss matters of poetry, politics, and philosophy. Long hours of discussion continued well into the night, with Mary Godwin being particularly fascinated and absorbed by the exchange of philosophical ideas between Byron and Shelley. ${ }^{3}$ As a lighter alternative for entertainment over the long evenings, ghost stories were always a pleasant digression. It was on one such occasion that, after reading from an old and very rare book of German ghost stories brought, probably, by Byron (Holmes 1994, 379), the lord had the idea of a writing contest, 
provoking everyone there to write a ghost story. Mary had been listening for some time enchanted by the discussions of Shelley and Byron as to the origin and meaning of life. Byron's young companion, a physician named Polidori, added to the discussions his very good knowledge of the latest medical practices, while Shelley remembered some of the experiments he did when studying. Electricity and galvanism were hot topics at the time. The result of this proposal, amplified by the extraordinary knowledge and skills of the circle, and augmented by the terrible climate, was a Gothic tale of horror that was to become the first modern novel of science-fiction: Frankenstein; or, the Modern Prometheus. Polidori also published a short story, The Vampyre, more of a pamphlet, introducing through it the theme of the vampire to a broader modern audience. The publication of his story would not bring him any fame though, rather trouble, as he was accused of plagiarizing Byron. It is possible that he wrote this story after one told on those evenings by Byron. Byron had been acquainted with the topic of vampirism during his travels to Greece and Albania, six-seven years earlier. In his poem "The Giaour", he had introduced the English reader already to the feared character. Polidori's account also mentions the legend as a specific superstition of the Balkan area. It must have been so, if we consider the attention paid by the Austrian authorities to the phenomenon of alleged vampirism in their Balkan territories in the eighteenth century. Maria Theresa's personal physician, a Dutch doctor named Gerard van Swieten (a source of inspiration for Bram Stoker in the creation of his character van Helsing), was put in charge of investigations in the region of today's Serbia and Bosnia to elucidate the strange stories of vampirism that were circulating in the area. He found, of course, nothing to support such superstitions, but it shows nevertheless the strong impact such legends had on people in the Balkan area.

\section{The Birth of the Modern Prometheus}

The fantastic creature that was introduced to the Western audience before the introduction of the modern vampire by Polidori has had a deep impact and resonance on European and world culture in the last two hundred years: the modern Prometheus. The bad weather of 1816 might have influenced the Byron-Shelley poetic circle in Geneva in their choice of long discussion on life and the role of man in the universe and of writing dark Gothic stories of horror, but the germs of the modern Prometheus lie much deeper in the general context of the age. The traumatic novel is the result of a traumatic age. The scientific and industrial revolutions resulted in a revolution of thought - the philosophy of the Enlightenment. The philosophers of the Age of Reason, starting with Thomas Hobbes and continuing with Voltaire, Rousseau, and Immanuel Kant, were pleading for a new social order, 
for a new world order. In that new order, people were to be guided only by their reason and to regain in this way their natural rights. Freedom, liberty, and equality of chances started to be viewed as the basic, fundamental rights of people, ideals everybody was invited to adopt and to help establish.

The political order, though, did not follow. The American Revolution was the first successful liberation movement that consecrated the modern philosophical, political, and social principles. In Europe, the immense tension that had been building up for centuries exploded eventually into the French Revolution. Liberals, democrats, progressists, and revolutionaries all over Europe and in America were thrilled. Their hopes were higher than ever; an ancient dream of man was within grasp, right there, in front of their eyes. For quite a few of them, the bitter disappointment that followed ${ }^{4}$ turned much of their enthusiasm into despair. Liberal and romantic thinkers and poets were trying to save the moment and animate people with their heroic poems of ancient times, populated with both benevolent and maleficent gods that were fighting each other over the fate of humankind. People were called to take their destinies into their own hands and overthrow man's corrupt system of power and return to a natural state of liberation, both physical and mental.

The context was ripe for the invocation of one of man's greatest heroes, the Titan Prometheus. The classical education of the time in Europe relied heavily on the classics of antiquity, tracing all roots of Western culture to the Greek and Roman worlds of ancient times. Such education would inspire Byron, Shelley, and his wife-to-be Mary to draw on the mythical figure of Prometheus as an embodiment of man's highest ideals of freedom. Mary though - and this is her highly innovative approach - chose not to follow the classical representation and instead turned Prometheus into a modern anti-hero. Inevitably influenced by her classical education, revolutionary parents, the historical context, and her entourage, she created a modern myth out of an ancient one, rearranging the eternal cycle of life and death and reinterpreting the role of creator and creation.

For an eighteen-year-old, to have produced such a fantasy novel seems almost incredible. From where to get such ideas when one is so young, ideas like using the dead to create living monsters? A possible answer is given by the traumatic events of that age. One of the most influential English philosophers of the time was still Edmund Burke, and his theories and opinions were widely circulated. In a 1796 letter written in his own defence, Burke relates some of the terrible events during the Great Terror period of the French Revolution:

They have hyenas to prey upon carcasses. The national menagerie is collected by the first physiologists of the time; and it is defective in no description of savage nature. [...]. Neither sex, nor age, nor the sanctuary

4 The Great Terror and the end of the Republic under Napoleon. 
of the tomb, is sacred to them. They have so determined a hatred to all privileged orders that they deny even to the departed the sad immunities of the grave. [...]. Their turpitude purveys to their malice; and they unplumb the dead for bullets to assassinate the living. If all revolutions were not proof against all caution, I should recommend it to their consideration that no persons were ever known in history, either sacred or profane, to vex the sepulchre, and, by their sorceries, to call up the prophetic dead, with any other event than the prediction of their own disastrous fate. (Burke 1903, 5; emphasis added)

Burke's reference is to the Revolutionary Exhumations at Saint-Denis in 1793, when the tombs of royalties and other prominent figures in French history were desecrated by legislative order in a symbolic gesture against all previous order. This governmental sacrilege by the profanation of tombs, meant also to destroy the memory of the French kings, sent a wave of shock and disgust throughout Europe. The earthly remains of the great leaders of the nation were dismembered and covered with quicklime for the rapid corrosion of the remains that were then dumped in common trenches (Lindsay 2014, 1).

Such stories made the headlines of European and British newspapers and were intensely discussed and debated upon. The case of Burke using that horrific event in a letter of defence is just one example. Mary Shelley must have known about that horrible desecration and that might have also been a source of inspiration for the novel. Frankenstein, the modern Prometheus, the scientist who believes he can help mankind by creating new life from the dead, is also desecrating tombs in order to accomplish his own scientific revolution. With no regard for the dead, no respect for those passed, this is already a universal taboo broken by the frantic, maniacal Frankenstein during his act of creation. In creating such a Promethean figure as Frankenstein, Mary might also premonish of a fate reflecting the revolution that ends up eating its own children. ${ }^{5}$ The unorthodox and uncontrolled use of science without moral restraint might end up destroying humanity. The reversed perception of the modern anti-hero's actions is that, while assuming for himself the role of a God, a Creator, instead of creating life from chaos, he turns life into chaos, risking not only the safety of himself and his beloved ones but also the fate of humanity. In this way, he does not bring order into a chaotic world, nor does he create a world from nothingness, but, on the contrary, risks destroying everything that has been achieved by humankind in its historical evolution. His actions are not altruistic and glorious acts to help his fellow man but lunatic pursuits of vanity for his own glory. He creates but is not capable of taking responsibility for his creation. He does not even dare

5 In a 1793 writing, Jacques Mallet du Pan introduced the expression "like Saturn, the Revolution devours its children". Saturn is the Latin version of Cronos, the first-generation Titan. 
to confront his creation but instead runs away cowardly, hoping that his deeds will remain unknown, that the monster will somehow vanish from the earth. When his creation traces his whereabouts and confronts him, he fails again, and again. The antithesis to the ancient myth and to the modern interpretation of Goethe, Byron, and Percy Shelley is complete. Everything in the development in the story predicts Frankenstein's own disastrous fate following his sacrileges and "sorceries", just as in Burke's vision of the French revolutionaries. The story might be the result of revolutionary disappointment and at the same time a warning for the future.

\section{Prometheus - The Original}

In his work Language and Myth, Ernst Cassirer makes a direct connection between the meaning of language and the meaning of myth. In his opinion, the interpretation of myths is not possible without the interpretation of the names of mythical heroes. The name, claims Cassirer, gives the actual identity of the characters and explains their actions and their roles.

Here in the realm of spooks and daemons, as well as in the higher reaches of mythology, the Faustian word seemed ever to hold good: here it was always assumed that the essence of each mythical figure could be directly learned from its name. The notion that name and essence bear a necessary and internal relation to each other, that the name does not merely denote but actually is the essence of its object, that the potency of the real thing is contained in the name - that is one of the fundamental assumptions of the mythmaking consciousness itself. (Cassirer 1953, 3)

For Cassirer, that theory becomes a "methodological principle" for discussing myths in a scientific and philosophical way. Following his method, we shall try to present the origin of the character and his name. Prometheus's name could be translated as "forethought" or "fore-thinker", and, by extension, association, and contextualization, even as "foreseer". His brother Epimetheus's name would mean as much as "afterthought", while his future wife bore the deceptive name of Pandora, meaning "all-gifts". The names of the two Titans, credited by several ancient sources with the creation of human and animal life on Earth, is symbolic for the dual nature of man. The two constantly colliding sides of man stand antithetical to each other in a permanent attempt to create the necessary balance to maintain the correct direction. While Prometheus, the fore-thinker, is constantly looking forward to the future, Epimetheus is looking at the past. Prometheus is depicted as intelligent, daring, and brave, while his brother is considered naïve 
and even foolish. Prometheus could "foresee" the poisonous gift that the trickery of Zeus sent in the form of Pandora, but Epimetheus nevertheless ignored all of his brother's warnings and advice. But Prometheus may also have suffered from his own weak nature. According to Hesiod's version of the myth, the first one to be transmitted, the lauded Titan and friend of humanity might also have had a darker side. Due to his recklessness and double play, instead of helping humans he actually brought the wrath of the gods upon them by his audacious actions. The well-known fire episode is second to the episode of the offerings to the gods, implying the sacrifice of an ox from which Prometheus trickily offered the bones wrapped in fat to the gods, while keeping the meat for the humans. The angry Zeus punished man for this, by forbidding him fire and thus the possibility of cooking his meat, forcing him therefore into an animal-like state. To repair his mistake, Prometheus stole fire from the gods, and this time was himself punished by Zeus. But people had to suffer even more. All pestilence was brought upon them by the "gifts" in Pandora's box, to which hope was cynically added for humans to keep enduring their miserable faith led by an illusory trust in a better fate. In a typical dual antithetical construct, the two Titan brothers represent the two sides of human character and personality. The two twin brothers are one entity with a dual nature. Prometheus's recklessness and double play and Epimetheus's foolishness seem to combine perfectly in Mary Shelley's Frankenstein. The visionary scientist is both reckless in his actions and foolish as not to recognize the disaster that he has brought upon his fellows. His creation seems to be more intelligent, more compassionate, and even more moral than its creator. Frankenstein is the forethought and the afterthought at the same time.

The second version of the myth is transmitted by Aeschylus, who transforms Prometheus into the divine hero of humankind, the one that stands by their side in their confrontation with the merciless gods of Olympus. This Promethean image is the typically romantic and revolutionary one, as expressed by Goethe, Byron, and Percy Shelley.

\section{Prometheus Reinterpreted: Twentieth-Century Visions}

The power of myths is amplified by crisis situations like wars, pandemics, revolutions, or natural disasters. In 1816, Europe was devastated by more than twenty years of the Revolutionary and Napoleonic Wars. The result: everybody wanted peace and rest. But this was hard to achieve as the wars effected, as usual, poverty, lack of resources, hunger, and despair. The cold and dark year of 1816 and the famine that followed overlapped with an already critical situation. But the most daring spirits were still lit up. England was part of the larger European effervescence that would eventually lead to events of the revolutionary year of 
1848 - even though, in a typically insular way, the British were more passionate towards reforms than revolutions. "Throughout England generally there was a powerful renaissance of the reform movement in the autumn of 1816" (Holmes 1994, 401). But this was not enough for hardliners and radicals like Percy Shelley. He would continue his ideas in Prometheus Unbound, on which he was working in 1818, giving Prometheus a political dimension, one to re-enact the eternal struggle for man's freedom. "Finally, in political terms, this is the moment of uprising and revolution against tyranny and imposed authority. Shelley is here not being nationally or even historically explicit. It is perhaps the old Illuminist ideal of world revolution, originally symbolized by a string of volcanic eruptions" (Holmes 1994, 580).

The idea of creating a new modern revolutionary myth out of the ancient myth of creation and emancipation of men is by no means adventitious with Percy Shelley. According to Harold Bloom, the major English romantic poets Blake, Wordsworth, Coleridge, Byron, Keats, and Shelley are mythmakers. Their efforts at creating or, actually, reinterpreting ancient myths and adapting them to express their romantic and revolutionary views are part of a larger romantic mythopoeia, an endeavour that resembles ancient struggles of Creation and translates into modern Titanism. "Blake, Byron, and Shelley are Prometheans, Titans" (Bloom 1959, 10). It is extreme Titanism that Byron and Shelley approach, like Blake before them (Bloom 1959, 60). Prometheus is a rebel against unnatural established order, a hero.

In Mary Shelley's Frankenstein though, he is the fallen hero, but not in the same way as in Milton's Paradise Lost. Her modern Prometheus contrasts with those of Goethe, Byron, and Percy Shelley. In her vision, he is not the stoic depicted in Cicero's Disputations nor the proud rebel against forced authority but, by contrast, merely the whimper of a whim. Frankenstein displays no stoic discipline nor proud rebellion but inconsistency, immaturity, lack of vision, and lack of understanding of man and of mankind, resulting in a personal failure of catastrophic proportions. Frankenstein is rather the modern rebel without a cause, disobeying and challenging the world without understanding it, trying to change it and bring a new order into it without being able to put order in his own life. His failure is catastrophic only for his own small universe, though he tries to endow it with universal significance. Mankind is left unafflicted, unaware even of his personal drama. Still, he sees himself as being responsible for the faith of the human race, believing he could destroy it by a double failure. This might only illustrate more his own perception of the self as a creator of unlimited powers, capable of both creation and the destruction of his creation. In this respect, he might resemble the Zeus of the Promethean poems of Goethe, Shelley, or Byron, a whimsical and tyrannical god that has already been outrun by his creation, the afterthought. Not even in his final collapse is he capable of understanding his 
moral failure. He is not able to really see and understand and take responsibility for his creation and his mistake. He runs from his creation, as he tries to escape reality by cowardly hiding and pretending that the monster is not there, or that it will disappear miraculously. He is hoping that his actions will have no consequences, not being able to take responsibility for his deeds. He cannot take action, cannot decide what to do, and seems to be in a state of inertia close to idiocy. No matter what the monster pleas for or threatens to do, he remains inert, hoping that it will pass. As Harold Bloom claims, the monster seems more human than its creator: more emphatic, capable of more intense human feelings and emotions, be they positive or negative. Mary Shelley's modern Prometheus shows himself as a weak god haunted by his own chimeras, destined to failure. There is nothing grandiose in him, as he proves to be inferior to his own creation, physically but also mentally, and even morally.

The greatest paradox and most astonishing achievement of Mary Shelley's novel is that the monster is more human than his creator. This nameless being, as much a Modern Adam as his creator is a Modern Prometheus, is more lovable than his creator and more hateful, more to be pitied and more to be feared, and above all more able to give the attentive reader that shock of added consciousness in which aesthetic recognition compels a heightened realization of the self. (Bloom 2009, 3)

Thus, Mary Shelley adapted Prometheus, "her enduring mythical hero" (Bloom 2009, 4), to the modern vision of men and gods, enveloping the mythical figure with the romantic rebellion and macabre darkness. Burdened by an age of great achievements and great disasters, of revolutionary utopias followed by grim dystopian realities, of high hopes and broken dreams, Mary Shelley gave birth to the modern Prometheus as the modern anti-hero, as failure: an Icarus that flew too close to the sun, a prophetic Titan turned into a whimsical Zeus, that plays with his creation he does not understand, being ultimately overrun and defeated by it. The foreseer becomes after-seer. Prometheus becomes Epimetheus, and his naivety and lack of clarity in vision and action opens a route that can lead only to disaster for all people. This type of the modern Prometheus would come closer to Mircea Eliade's interpretation of the ancient Prometheus as the one who, through carelessness, double play, and deceit, ultimately brought plagues and disasters to mankind:

All in all, far from being a benefactor of humanity, Prometheus is responsible for its present fallen state. At Mekone he instigated the separation between men and gods. Then, by stealing fire, he exasperated Zeus and thus caused the invention of Pandora [...] and, in consequence, the propagation of 
all kinds of cares, tribulations, and misfortunes. For Hesiod, the myth of Prometheus explains the sudden coming of evil into the world; in the last analysis, "evil" represents the vengeance of Zeus. (Eliade 1978, 256-257).

Eliade distinguishes further between the Hesiodic and Aeschylean representations of Prometheus: "For Aeschylus, who substitutes the theme of progress for the myth of the primordial golden age, Prometheus is the greatest civilizing hero" (Eliade 1978, 257). These two types of representations seem to have worked in the case of the Byron-Shelley circle in 1816 and thereafter. While Byron and Percy Shelley embraced Aeschylus's vision of Prometheus, Mary took a different turn, possibly after her curious and thorough observations of the two great poets, sensing perhaps a duality in their natures that made them titanic both in success and in failure.

In the same line of interpretation, Eliade continues: "The first men, Prometheus affirms, lived 'underground, deep in caverns closed to the sun'; they did not even know the succession of the seasons or the domestication of animals or agriculture" $(1978,257)$. This state of mankind is similar to the one described by Byron in his poem "Darkness", written in July 1816 in Geneva. Byron, although a follower of Aeschylus's version of the myth, seems to have experimented himself with a darker vision of creation and destruction in the summer of 1816 in Geneva, at the same time Mary was already dreaming of Frankenstein, and even if Prometheus is not explicitly mentioned in the poem "Darkness", we know how much influence the myth was for all his writing. ${ }^{6}$ The poem describes the end of men and of all life on Earth, brought about by the disappearance of the sun, moon, and stars. Wild animals become domesticated by themselves, getting closer to people in those final moments of life, but man, even reduced to only two last survivors, is still his worst and most terrible enemy. The dim light these last two survivors spark from the remains of an altar is cast upon their appalling and decaying, starving features and, at the terrifying sight of each other, they both die of fear. Northrop Frye's identification of fire and heaven with Promethean myth and apocalyptical images may give an additional interpretation of Byron's poem: "In Classical mythology the story of Prometheus indicates a similar provenance for fire, as does the association of Zeus with the thunderbolt or fire of lightning. In short, heaven in the sense of the sky, containing the fiery bodies of sun, moon, and stars, is usually identified with, or thought of as the passage to, the heaven of the apocalyptic world" (Frye 1957, 145). This apocalyptical Byronic approach

6 In a letter to his publisher John Murray, dated 17 September 1817: "Of the Prometheus of Aeschylus I was passionately fond as a boy (it was one of the Greek plays we read thrice a year at Harrow); - indeed that and the Medea were the only ones, except the Seven before Thebes which ever pleased me. The Prometheus if not exactly in my plan, has always been so much in my head, that I can easily conceive its influence over all or any thing that I have written" (Byron 1904, 174-175). 
is antithetical to the world described by Aeschylus, where Prometheus freed men from their fear of death. Lord Byron would choose again the Aeschylean approach for his poem "Prometheus" of the same year, following his political and revolutionary credo, but Mary Shelley stayed with her vision of choice, emphasizing the duality and the antithetical nature of her modern Prometheus, this time in line with the visions of the great romantic poets:

The antithesis between the scientist and his creature in Frankenstein is a very complex one and can be described more fully in the larger context of Romantic literature and its characteristic mythology. The shadow or double of the self is a constant conceptual image in Blake and Shelley and a frequent image, more random and descriptive, in the other major Romantics, especially in Byron. In Frankenstein, it is the dominant and recurrent image and accounts for much of the latent power the novel possesses. (Bloom 2009, 2)

\section{Conclusions}

If in myths and legends as well as in their poetic emulations of the early-nineteenthcentury English romantics' creation and destruction are often seen as heroic, or artistic, sometimes apocalyptical, Mary Shelley's Frankenstein and The Last Man or Lord Byron's "Darkness" envision less glorious endings of men. The darkness that surrounds such writings is strong enough to draw the weak characters in the stories and manipulate them, but the moral of such stories is actually a glorification of life. Such apocalyptical creations as the above mentioned are warnings about the future cast in times of great distress. There is always a story to tell, and therefore a storyteller. If there is no one left to tell the story, there is no story. The idea behind those stories is that of survival, of hope, of a new chance, a new beginning. It is more of a warning, in such writings, against the senselessness of people and their arrogance, and not necessarily the morbid vision of the authors. Authors of such writings seem to be rather in love with and fascinated by life, and not desperately attracted to death. Their expression is artistic sensibility horrified and disgusted by the vulgar pursuit of immediate rewards, the adoration of false idols in the ultimate form of absolute power, and the inertia of humankind. The invocation of Titans in poems like Goethe's and Byron's "Prometheus" and Shelley's "Prometheus Unbound" are also calls to battle, for people to fight for their freedom, liberties, and rights - for their very lives.

The context of war, revolutions, pandemics, and natural disasters as illustrated by the great volcanic eruptions of 1783-1815 created the proper conditions for a re-evaluation of classical myths, be it in a revolutionary mode as by Percy Shelley 
and Byron or through the modern anti-hero with Mary Shelley. It is most likely with her that Prometheus enters modernity. People tend to be influenced by catastrophic events, even more so when these follow each other over a short period of time or even overlap. The traumatic events of the fourteenth-century Great Famine and Black Death, the Great Plague of London followed immediately by the Great Fire of London, and, finally, the combined natural and social events that culminated with the French Revolution and early-nineteenth-century modern revolutionary spirit left deep marks in literature. During English Romanticism, they were transposed into literature by titanic figures such as Blake, Byron, and Shelley, with a fresh and intriguing modern perspective introduced by Mary Shelley in her apocalyptical science-fiction novels Frankenstein; or the Modern Prometheus and The Last Man. The myth of Prometheus came in handy for the poets of the time, conscious and anxious about the shifts of their time: "In the industrial age, however, Prometheus, who stole fire for man's use, is one of the favourite, if not the actual favourite, mythological figure among poets" (Frye 1957, 155).

Natural disasters also helped shape the modern myth, with poets finding proper ground for the symbolic interpretation of motifs of the Enlightenment. If the god Vulcan chained Prometheus to the rock by the order of Zeus, and Hercules, to his great honour, liberated him, the great volcanic eruptions of 1783-1815 created at least some background for a change in nature that contributed to the constantly changing human nature in the turbulent decades at the end of the eighteenth and the beginning of the nineteenth century. Human character changed as well. The romantic poets and rebels took against the tyrannies of their societies, be they political, social, moral, or religious, and challenged the "gods" of their time in a Herculean attempt to free the Prometheus in us, in all the people. In their poetry and prose, they incited to the liberation of all the people, from all their constraints. Byron even fought and died for the noble cause of liberty. Their legacy is still valid. And their Promethean examples might inspire us today in our own times of crises. We can only wonder how Prometheus might be reinvented today, in the light of the social reactions generated by the coronavirus pandemic, perhaps by the next Shelley, newly inspired whilst whiling away the evenings trapped in some alpine Covid lockdown bolthole with poet-philosopher friends. 


\section{Works Cited}

Bloom, Harold. 1959. Shelley's Mythmaking. New Haven: Yale University Press. 2009. Mary Wollstonecraft Shelley. New York: Bloom's Literary Criticism, Infobase Publishing.

Brönnimann, S. and Krämer, D. 2016. Tambora and the "Year Without a Summer" of 1816. A Perspective on Earth and Human Systems Science. Geographica Bernensia G90, 48 pp., DOI:10.4480/GB2016.G90.01.

Burke, Edmund. 1903. Letter to a Noble Lord. Boston: The Athenaeum Press.

Byron, Lord. 1904. The Works of Lord Byron - Letters and Journals, Vol. IV. London: John Murray.

1905. The Works of Lord Byron - Poetry, Vol. IV. London: John Murray.

Cassirer, Ernst. 1953. Language and Myth. New York: Dover Publications Inc.

Defoe, Daniel. 1722. A Journal of the Plague Year. London. https://gutenberg.org/ files/376/376-h/376-h.htm (Last accessed 2 April 2021).

Eliade, Mircea. 1978. A History of Religious Ideas, Volume 1. From the Stone Age to the Eleusinian Mysteries. Chicago: The University of Chicago Press.

Frye, Northrop. 1957. Anatomy of Criticism. Four Essays. Princeton and Oxford: Princeton University Press.

2005. Collected Works of Northrop Frye, Volume 17. Northrop Frye's Writings on the Eighteenth and Nineteenth Centuries. Toronto: University of Toronto Press.

Goethe, Johann Wolfgang von. 1789. Goethe’s Schriften, Achter Band. Leipzig: G. J. Göschen.

Holmes, Richard. 1994. Shelley. The Pursuit. New York: The New York Review of Books.

Kant, Immanuel. 1784. “Beantwortung der Frage: Was ist Aufklärung?” [An Answer to the Question: What is Enlightenment?]. Berlinische Monatsschrift vol. 4, no. 12: 481-494.

Lindsay, Suzanne Glover. 2014. "The Revolutionary Exhumations at St-Denis, 1793." Essay. Conversations: An Online Journal of the Center for the Study of Material and Visual Cultures of Religion. https://mavcor.yale.edu/sites/ default/files/article_pdf/lindsay_suzanne_glover_pdf.pdf (Last accessed 2 April 2021).

Polidori, John William. 1819. The Vampyre; A Tale. London. https://www. gutenberg.org/files/6087/6087-h/6087-h.htm (Last accessed 2 April 2021).

Wollstonecraft, Mary. 1999. A Vindication of the Rights of Men. A Vindication of the Rights of Woman. An Historical and Moral View of the French Revolution. New York: Oxford University Press. 